\title{
Revisitando o passado em tempos de crise: federalismo e memória no período regencial (1831-1840)
}

\author{
Luiz Geraldo Santos da Silva \\ Ariel Feldman
}

\section{Introdução}

Este artigo tem por objetivo analisar o processo de construção de memórias em torno da Revolução de 1817 e da Confederação do Equador (1824) ao longo do período regencial (1831-1840). Tal processo foi levado a efeito, sobretudo através da imprensa periódica daquele período. Nossa proposição mais geral consiste na ideia segundo a qual a tarefa de elaboração de uma contra-memória acerca daqueles eventos representa um dos componentes ideológicos que contribuíram para a conclusão do complexo e turbulento processo de construção de um Estado unitário no Brasil. Tal processo urgia por soluções e encaminhamentos práticos particulares ao início das regências, período o qual, como se sabe, foi marcado por graves ameaças à unidade do Império e por importantes redefinições políticas e institucionais. ${ }^{1}$ Privilegiamos, dentre os periódicos daqueles anos - seguramente o que mais viu gazetas nascerem para, poucos meses depois, desaparecerem do espaço público ${ }^{2}$ - o jornal O Carapuceiro, publicado entre 1832 e 1842 por um único jornalista: o padre, professor de retórica e deputado do Império, Miguel do Sacramento Lopes Gama (1791-1852). Ardoroso defensor da "monarquia constitucional representativa contra as ideias absolutas de uns, e as democráticas de outros" - como formulou um de seus vários biógrafos $^{3}$ - este foi, seguramente, um dos mais influentes gazeteiros da primeira metade do século XIX. Nascido no Recife, Lopes Gama foi jornalista responsável por vários periódicos publicados em Pernambuco entre 1820 e 1850. Dentre estes destacamos O Conciliador Nacional (1822-1825), O Constitucional (1829-1831) e O Sete de Setembro (1845-1846). ${ }^{4}$

Enquanto os periódicos do tempo das regências nasciam e morriam em poucos meses, como já observamos, $O$ Carapuceiro manteve-se em circulação por longos dez anos, sendo publicado não apenas no Recife, mas também na corte fluminense e em outras cidades do Império. Dentre todos os periódicos publicados por Lopes Gama foi, seguramente, o mais bem sucedido, bem como o de mais ampla circulação. ${ }^{5}$ Assim sendo, o fato de uma contra-memória acerca da Revolução de 1817 e, principalmente, da Confederação do Equador ter sido forjada em suas páginas produziu forte impacto sobre o olhar retrospectivo em torno daqueles eventos. No entanto, sustentamos aqui que o passado, em si mesmo, parecia significar muito pouco na análise do Padre Carapuceiro - como ficou conhecido graças à sua gazeta semanal. Seu olhar retrospectivo, marcado por uma interpretação negativa das práticas políticas daqueles movimentos contra o Reino Unido e contra o primeiro imperador ${ }^{6}$, tinha como finalidade, ao fim e ao cabo, criticar ideias e padrões da luta política vigentes ao tempo das regências. Assim, olhando para o passado, Lopes Gama construía um projeto de futuro. Formulava, então, projeto marcado pela moderação monárquica e constitucional, e alicerçava fundamentos da unidade do Império em meio à emergência de forças sociais centrífugas no Pará, no Rio Grande do Sul e na Bahia e de forças centripetas em Pernambuco e na própria corte.

Por outro lado, parece estranho utilizar-se aqui de um jornal como O Carapuceiro como fonte de debate, memórias e projeções de futuro de caráter político, uma vez que ao longo de mais de um século seus artigos foram essencialmente interpretados como crônicas de costumes. ${ }^{7}$ Entretanto, em trabalho recente, demonstrou-se que este jornal exerceu forte influência política nos espaços públicos durante o período regencial. Verificou-se igualmente que o estilo sedutor do jornal, a princípio destinado a criticar maus hábitos e costumes, acabou, paradoxalmente, por torná-lo importante instrumento de defesa 
e sustentação de ideias políticas. Ademais, à época de sua publicação, $O$ Carapuceiro era lido como um periódico com "deveres políticos" e "patrióticos", a despeito das alegações em contrário de seu articulista. Numa polêmica ocorrida entre junho e julho de 1834, na qual se envolveram Lopes Gama e Cipriano José Barata de Almeida (1762-1838) - e sobre a qual voltaremos a falar adiante -, este aspecto ganha bastante relevo.

Gama publicara, na edição d'O Carapuceiro de 21 de junho de 1834, artigo no qual definia o tipo "federalista de já e já" - operação mental, aliás, bastante recorrente em seus escritos. "Federalistas de já e já" eram "grandes matreiros", "ávidos pescadores, que querem pescar nas águas envoltas à custa dos tolos, que lhes servem de isca", além de serem "homens das facilidades", que tinham certeza da participação de todas as províncias no "pacto social". Mas tal pactuação era, em princípio, incerta e temerária, o que colocava em risco a unidade do país, tornando-o sujeito à revolução. Insiste Gama que se evitasse "toda e qualquer revolução, e muito mais uma revolução que se dirige a refundir a Constituição, e tocar em o Paládio da nossa salvação, que é sem dúvida o Augusto Menino, que a providência outorgou-nos". ${ }^{8}$

Por sua vez, na edição de 16 de julho de 1834 de seu Sentinela da Liberdade na sua Primeira Guarita, a de Pernambuco, onde Hoje Brada Alerta!!, Cipriano Barata de Almeida critica a noção de "federalista de já e já" e argumenta, em artigo intitulado "Breve análise à Gazeta $O$ Carapuceiro", que nesta se gastava tempo "combatendo Federação já e já (sem dizer em [que] termos)", quando, na verdade, "devia ser folha de oposição ao atual sistema ministerial". Barata critica a falta de engajamento de Gama na luta contra os restauradores, e adverte que a enorme popularidade de sua folha semanal, desde seus dois primeiros anos de existência, tornava-a influente na direção tomada por amplos setores da opinião pública. "O Carapuceiro", aduz Barata, "tem por dever iluminar os seus concidadãos e ajudar a Sentinela a sustentar os direitos da Pátria e a liberdade contra os Restauradores (aos Infernos vão eles parar). E repare aquela Gazeta que os homens, mestres e meninos póem os olhos nela". ${ }^{9}$ Barata sublinha, pois, além de sua popularidade, o caráter político do jornal em questão, aspecto que, embora notado pelos contemporâneos, foi sepultado por folcloristas e historiadores posteriores, que nele viram, sobretudo, seu caráter costumbrista. Estes certamente deixaram-se iludir por Lopes Gama, o qual, ao final do artigo em que responde a Barata, intitulado "Resposta à Gazeta Sentinela da Liberdade Número 20", ${ }^{10}$ argumenta: "O meu pobre Carapuceiro ocupa-se da moral; e só per accidens, de Política. Permita a Providência, que o Ilustre Sentinela brade sempre o propósito e encaminhe o Povo pela estrada convenientemente segura, dando-lhe conselhos saudáveis de uma Política Ilustrada". ${ }^{11}$

Em suma, embora ostentasse o disfarce de "periódico sempre moral e só per accidens político", como reza seu subtítulo, afirma-se aqui que $O$ Carapuceiro foi, antes de tudo, um jornal essencialmente político, tal como, ademais, era lido e percebido à época de sua publicação. Postula-se também que seu invólucro costumbrista, que lhe rendeu profunda influência no espaço público da era das regências, facilitoulhe a tarefa de propagação ideológica conservadora, propugnando as vantagens do Estado unitário e da monarquia constitucional. ${ }^{12}$

\section{Federalismo versus Estado Unitário}

As tensões entre, por um lado, projetos políticos federalistas - cuja ênfase reside na busca por mais poderes e atribuições às províncias - e, por outro lado, projetos de reiteração do Estado unitário - os quais se esforçam por garantir maior centralização das rendas e do poder político no governo do Império - constitui, atualmente, tema bastante debatido pela historiografia. ${ }^{13}$ Não se pode, contudo, confundir federalismo com separatismo, nem tampouco associar federalismo apenas aos grupos mais exaltados daqueles anos. Como bem nota Marco Morel, o separatismo não foi "atributo exclusivo dos liberais Exaltados de tendências republicanas, como em geral a historiografia aponta". ${ }^{14}$ Os grupos restauradores do início da década de 1830 que almejavam o retorno de D. Pedro I após sua abdicação revelam tendências separatistas mais pronunciadas que os grupos exaltados dos mesmos anos. Chefes militares 
restauradores referiam-se amiúde à separação das províncias do Norte para formar um novo império, a ser denominado Equador ou Amazonas, caso não concretizassem o retorno do primeiro imperador ao Brasil. ${ }^{15}$ Como veremos adiante, ao examinarmos o discurso de Lopes Gama nos primeiros anos da década de 1830, notamos que este passa, então, a defender o federalismo, mesmo que com ressalvas e conservadoramente. Sua intenção, ao assim proceder, longe estava, evidentemente, de apoiar quaisquer formas de separatismo. Antes, é visível em seu discurso, e desde fins de 1822, quando redigia $O$ Conciliador Nacional (1822-1825), a defesa intransigente da unidade e indivisibilidade do Império. Não por acaso, pois, externou seu apoio à repressão imperial à Confederação do Equador, o que lhe fez merecedor de recompensas em forma de cargos públicos, como veremos adiante. ${ }^{16}$

Contudo, se no início da década de 1830 ele foi partidário de um federalismo de matizes conservadores, no final da mesma década defendeu apaixonadamente o regresso conservador, ${ }^{17}$ cuja principal tarefa consistiu na reversão de muitas das prerrogativas obtidas pelas províncias através do Ato Adicional de 12 de agosto de $1834 .{ }^{18}$ Segundo a historiografia preocupada com açōes e projetos da elite política imperial e, particularmente, do grupo saquarema, o regresso acabou por cimentar o processo de centralização político-administrativa do Império, fazendo o peso da balança voltar a pender em favor do Estado unitário, em detrimento da federação. ${ }^{19}$ Este, aliás, era projeto acalentado pelo grupo dirigente que mais tarde formaria o Partido Conservador, o qual se consolida com a interpretação do ato adicional de 12 de maio de 1840 - que praticamente anula todas as conquistas federalistas obtidas em 1834. ${ }^{20}$ Para entender as mudanças de posição de Gama - da defesa do federalismo, mesmo que moderado, ao apoio ao regresso - é preciso pôr em revista tendências existentes tanto em Pernambuco como no Império ao longo das décadas de 1820 e 1830.

Entre 1821 e 1824, duas tendências políticas discerníveis alternaram-se no poder em Pernambuco: a primeira era a dos federalistas, e a outra era a favorável ao reforço do Estado unitário. Tais tendências reproduziam, portanto, no âmbito provincial, as mesmas tensões que vimos analisando até agora no conjunto do Império, isto é, a defesa liberal da autonomia das províncias, por um lado, e, por outro, a centralização das rendas e das decisōes governamentais no nível do governo imperial. As alternâncias de poder em Pernambuco apenas tiveram fim em julho de 1824, quando esses grupos enfrentaram-se numa guerra civil apenas concluída nos primeiros meses do ano seguinte. Referimo-nos ao movimento político conhecido por Confederação do Equador. Este, segundo a historiografia nativista local, bem como segundo a historiografia saquarema, ${ }^{21}$ representa, sobretudo, um confronto entre as províncias do Norte e o Império nascente. Mas acreditamos, como já foi observado, tratar-se principalmente de uma guerra civil, isto é, de confrontação direta pelo poder, interna aos grupos políticos provinciais, da qual sai vitorioso o grupo defensor do Estado unitário apoiado pelo imperador D. Pedro I. Este, enfim, impôs seu projeto político aos federalistas derrotados, garantindo a adesão das províncias do Norte aos "negócios do Rio", como formulou Frei Caneca em seu Typhis de 10 de junho de $1824 .{ }^{22}$

Em fins de 1824, após a derrota dos confederados, Lopes Gama, como já anunciamos, foi agraciado com cargos públicos. Torna-se primeiro diretor do Liceu Pernambucano, visitador das escolas públicas e diretor da única tipografia existente na província. Como diretor do Liceu, decreta que todos os alunos, ao ingressarem na escola, deveriam jurar a constituição outorgada pelo imperador. Tal atitude, constrangedora para a época, era absolutamente repulsiva do ponto de vista dos federalistas, os quais, como se sabe, se negaram a jurar a constituição outorgada em $1824 .{ }^{23} \mathrm{Um}$ panfleto de 1825 atribuído a Lopes Gama, intitulado Diálogo entre um Corcunda, um Constitucional e um Federativo do Equador, exibe escárnio ao grupo político derrotado. ${ }^{24} \mathrm{O}$ próprio título do panfleto elabora uma importante distinção: ser constitucional era distinto de ser federativo. Ambos exigiam uma constituição que regesse a política de Estado, mas o primeiro não classificava a dissolução da Assembleia Constituinte, em fins de 1823, como rompimento com a soberania da nação. Dom Pedro, segundo o Constitucional, exercera seus legítimos direitos ao outorgar uma Carta Magna no ano seguinte. Por seu turno, para o Federativo do Equador a dissolução da Assembleia significou, entre outros aspectos, a negação dos direitos das 
províncias de participar do processo de elaboração da lei máxima da nação, o que justificava o rompimento de algumas delas com o despótico Estado unitário e imperial sediado no centro-sul do Império. Tudo leva a crer que o ponto de vista do Constitucional é o mesmo defendido por Lopes Gama, não só naqueles anos, mas também mais tarde, nos anos da regência. Tal como faria a partir de 1832, ao redigir $O$ Carapuceiro, utilizava em 1825 uma forma dialógica, indireta e cômica, de divulgar sua defesa do Estado unitário e da monarquia constitucional.

Percebe-se, pois, que na primeira metade da década de 1820, Lopes Gama colocou-se enfaticamente contra projetos de tipo federativo. Mas, como demonstraremos adiante, seu posicionamento altera-se ao início das regências, mas não radicalmente, para depois sofrer nova guinada conservadora posteriormente ao regresso conservador. Tal guinada não decorria de possível esquizofrenia política de nosso personagem. Antes, como se verá adiante, Lopes Gama defende algumas reformas na direção do federalismo no início da década de 1830, mas de forma tímida e parcial, uma vez que seu foco era o reforço do poder do segundo imperador e a defesa intransigente de sua noção de monarquia constitucional. A análise da contra-memória por ele elaborada acerca da Revolução de 1817 e, sobretudo, da Confederação do Equador, sempre evocada em seu exame do federalismo, pode nos ajudar a entender a particularidade de seu pensamento político.

Já foi demonstrado em trabalhos recentes que os federalistas de 1824 não pretendiam sequer algo semelhante à secessão das províncias do Norte. Defendiam, antes, um projeto político para toda a nação brasileira, do "Amazonas ao Prata", como se dizia à época da independência, e exigiam que o imperador cumprisse o que prometera no decreto de dissolução da Assembleia Constituinte, isto é, que convocasse "nova Assembleia", como diz aquele documento. ${ }^{25}$ Ademais, os federalistas pernambucanos foram pegos de surpresa quando D. Pedro forçou os constituintes a votarem favoravelmente em outro decreto, este de 20 de outubro de 1823, o qual dissolveu todas as Juntas de Governo criadas ao tempo das Cortes Constituintes da Nação Portuguesa e criou "provisoriamente" a instituição do presidente de provincia - a qual, contudo, duraria ao longo de todo período imperial. O presidente, como reza sua lei de criação, "será o executor e administrador da Província, e como tal estritamente responsável: será da nomeação do Imperador, e amovível, quando o julgar conveniente". ${ }^{26}$ Coube a um desafeto dos federalistas, o morgado do Cabo, Francisco Paes Barreto, tornar-se primeiro presidente da província. Barreto estivera por trás do golpe de Estado que levou à deposição da primeira Junta de Governo, presidida por Gervásio Pires Ferreira, a qual governara a província de 26 de outubro de 1821 a 16 de setembro de 1822 . Ao mesmo tempo, integrara a chamada Junta dos Matutos, composta integralmente por defensores do Estado unitário, cujo governo estende-se de outubro de 1822 a novembro de 1823 . Foi esta Junta que pavimentou a entrada dos "negócios do Rio" em Pernambuco, facilitando os termos constitucionais de sua adesão ao primeiro imperador. ${ }^{27}$

Ao longo da primeira metade de 1824 os federativos pernambucanos exigiam distinto presidente de província, bem como se negavam a jurar a Constituição outorgada. Contudo, as poucas negociações entre eles e Dom Pedro redundaram em fracasso, o que levou, como última instância, à proposta de separação das províncias do Norte. Era a última cartada dos federativos. Tratava-se, portanto, de solução não imaginada a princípio, e tomada no calor dos acontecimentos, isto é, ao improviso, sem que se fizesse avaliação acurada das forças militares federalistas em sua luta não apenas contra o Império e seus mercenários ingleses e franceses, mas principalmente contra o grupo centralista e suas milícias locais. Em decorrência dessa falta de cálculo político e militar, Lopes Gama qualificou a Confederação do Equador em vários de seus escritos das décadas de 1830 e de 1840 como um evento "quixotesco". No início da década de 1830, ao iniciar a publicação de $O$ Carapuceiro, dará início à sua defesa de alguns princípios federalistas, aspecto que deu ensejo a polêmicas ácidas, veiculadas pela imprensa periódica, bem como a criação da contra-memória da Confederação do Equador a que nos referimos anteriormente. Afinal, era preciso apontar os excessos do unitarismo nesse momento, intimamente associado às 
ações dos restauradores, os quais ameaçavam a integridade do Império, à medida que procuravam restituir a Dom Pedro o trono perdido. Contudo, tal defesa deveria ser empreendida sem outros excessos vinculados às práticas dos "federalistas do Equador", por ele duramente criticados desde a repressão a este movimento político. Por outras palavras, era preciso instituir padrões de governação federalistas, após o malogro do primeiro reinado e da revolução de 7 de abril. Contudo, ao mesmo tempo, fazia-se imperioso ressaltar que tal defesa nada tinha a ver com o passado de lutas políticas levadas a efeito na província de Pernambuco, as quais estavam atadas ao perigoso e temido léxico da revolução. Assim, pois, na edição de 16 de janeiro de 1833 de $O$ Carapuceiro, Lopes Gama brada duramente contra a suspeita de "...que daquele Rio de Janeiro nos vem todo o mal. Não há a menor dúvida que ali existe um partido de Figurões, inimigos jurados da Federação, unitários por cálculo, e que não podem tragar que as Províncias se subtraiam à mais estrita dependência da Corte, onde eles tudo põe, e dispõe a seu talante". Travestia-se, então, em ardoroso defensor do federalismo. ${ }^{28}$

Não por acaso, nestes mesmos meses de 1833 é publicada missiva, no Diário de Pernambuco, cujo autor atendia pelo pseudônimo de Carapuceiro do Carapuceiro. Conforme este, Lopes Gama seria hipócrita ao defender, no tempo das regências, o sistema federativo, contrariamente ao modo como procedera na década anterior. O Padre Carapuceiro, no entanto, se defende prontamente, argumentando que

É verdade que eu reprovei muito a Federação chafana, com que saíram alguns estouvados no tempo da memoranda coluna, e que hoje escrevo o Federalista, e entendo que já nos convém a Federação: e haverá nisto contradição? Os tempos são os mesmos? São idênticas as circunstâncias? Para haver contradição (ensina-nos a Lógica) é mister que haja - Afirmatio, et negatio ejusdem, de oedem, et sub eodem respectu -. Uma cousa pode não convir-nos hoje, e ser-nos útil amanhã: há 40 anos, por exemplo, seria louco o que quisesse um Governo Representativo para Pernambuco; mas hoje convêm-nos muito. ${ }^{29}$

O cerne de sua adesão repentina ao federalismo nos primeiros anos da regência era o ataque aos "colunas do trono e do altar", ou restauradores, que ameaçavam o Império por aqueles anos da mesma forma temível que os federalistas dos anos anteriores o haviam feito: com a revolução e o separatismo. Sua leitura da Confederação do Equador, ou a criação de uma contra-memória em torno desse evento, consistia, por um lado, na condenação de seu teor revolucionário e separatista, e, por outro lado, na depuração do seu federalismo. Este, na nova ordem das regências, além de antirrevolucionário e antisseparatista, deveria ser pró-monárquico, pró-constitucional e pró-integridade territorial do Império. A árdua tarefa de defender o federalismo e condenar a revolução levou-o a elaborar os termos daquela contra-memória. Não por acaso, nesta construção ideológica do passado, tal movimento político era descrito pela expressão "revolução de 1824". Na mesma edição de 23 de fevereiro de 1833 , Gama escreveu a esse respeito que

Nunca aplaudi a revolução de 1824; antes, muito a reprovei... Eu não duvidei nunca da boa intenção dos Patriotas de 24; mas sempre chamei de desassisada aquela empresa, tanto assim que no Conciliador [Nacional] tive a franqueza de dizer, então, que não tinha por crime o que fizeram os Carvalhistas; mas sim por loucura. ${ }^{30}$

Assim, pois, Lopes Gama, mesmo defendendo o sistema federativo nestes primeiros anos do período regencial com o fito de atacar os "colunas do trono e do altar", sustenta a opinião de que a "revolução de 1824" foi um ato impensado, e que aquele não era o momento político para instituir-se federação no Brasil. Na polêmica que trava com Cipriano Barata de Almeida, entre junho e julho de 1834, adiciona mais alguns traços ao seu federalismo, elementos estes que o distinguem dos federalistas da Confederação do Equador. Ao mesmo tempo, aproveita o ensejo para condenar a prática de toda e qualquer revolução, mas, sobretudo daquela levada a efeito em 1824. No artigo já referido, e intitulado "O que é um Federalista de já e já", Lopes Gama inicia argumentando que tal sistema era então fundamental à governação imperial: 
Conheço a necessidade que tem o Brasil de algumas Reformas na sua constituição, mormente naquelas cousas que dizem respeito à servil e pesada dependência em que estão as Províncias a respeito da Corte: mas no modo de efetuar essas reformas é que está quanto a mim toda a dificuldade: porque entendo que estas deverão ser arranjadas de tal arte, que em nada prejudique a integridade do Império, nem se ofendam as atribuições do senhor Dom Pedro $2^{\circ} .{ }^{31}$

As pedras de toque do federalismo de Lopes Gama eram o respeito ao jovem imperador, por um lado, e à integridade do Império, por outro. Conceder poderes em excesso às províncias e, ao mesmo tempo, subtrair poderes ao monarca condenaria o país à anarquia. Sua defesa radical consistia em conservar "ileso o Paládio do Trono Constitucional na Augusta Pessoa do Jovem Imperador", bem como em evitar um quadro marcado por um "Brasil retalhado em províncias de todo independentes", "facilmente vulneráveis" e "presa de qualquer empreendedor ousado". ${ }^{32}$ Finalmente, Lopes Gama acusa o "Federalista de já e já" da pior pecha possível, conforme seu léxico conservador: a de revolucionário: "...evitemos cuidadosamente toda e qualquer revolução", diz ele, "e muito mais uma revolução que se dirige a refundir a Constituição e tocar em o Paládio da nossa salvação, que é sem dúvida o Augusto Menino, que a providência outorgou-nos". Os riscos da revolução estavam, aliás, como sempre, nas suas memórias de 1817 e, principalmente, de 1824:

Já está em idade de conhecer os homens, e nunca que esquecerá o que observei em 1817 e ainda mais em 1824. Não poucos, que se prestaram a esta Revolução e depois levavam... proscritos ao Excelentíssimo General Lima, a quem muitas vezes vi enfurecido contra semelhantes infames e traidores. A História, essa grande mestra da vida, nos ensina que os homens de extremos são os mais perigosos em todas as mudanças políticas. ${ }^{33}$

Em sua crítica ao artigo "O que é um Federalista de já e já”, de junho de 1834, Barata argumenta, em meados do mês seguinte, que se "a Federação deve acudir-nos já e já não se indica por isto desordem e desatino, como dá entender o Carapuceiro". ${ }^{34}$ Antes, argumenta Barata, "o que se deve coligir é que não é de razão perder o tempo metendo delongas. $\mathrm{O}$ que é necessário... não se pode dispensar e nos apertos e crise em que estamos não parece convir esperar muito" ${ }^{35}$ Ademais, este advoga, como todos os intelectuais e publicistas da época, fossem restauradores, exaltados ou moderados, o desejo de união das províncias, contrariando a perspectiva saquarema de nossa historiografia, conforme a qual a tarefa de construção da unidade territorial é obra exclusiva dos conservadores: "Deus me livre de falar de desunião das províncias e o Carapuceiro faz mal em tocar nisso. Brasileiros, em todo caso, união e bem união... e concórdia, pedindo boas reformas já e já em termos" “ ${ }^{36}$ Sua crítica também se dirige à ideia, repetidas vezes formuladas por Gama, em torno da figura do "jovem imperador" como "Paládio da nossa salvação": "O paládio geral", objeta Barata, "é o sistema liberal e a boa Constituição, e nunca o chefe do poder executivo, não obstante o amor que lhe consagramos". ${ }^{37}$ Sua crítica principal era, enfim, dirigida ao temor contra-revolucionário de Gama, e, sobretudo, à sua indisfarçada construção da contra-memória da Revolução de 1817 e da Confederação do Equador:

Também me parece pouco exato quando apresenta como prova de seus ditos as revoluções de 1817 e 1824, porque dizem os sabedores da guerra que não se perderam, senão pela falta de opinião geral e Engenheiros, e muito principalmente por traição de alguns Pernambucanos infames e servis, acrescentando-se à primeira jactância dos mesmos que supunham vencer batalhas com festas, casamentos e vivas. ${ }^{38}$

Para Barata, que "o Carapuceiro, reprovando as revoluções, diz que elas não se fazem de empreitada... nisto tem razão”. O que ele não parece concordar é com a interpretação de Lopes Gama que lhe permite falar "em revolução como se fora o pão nosso de cada dia e brinco de meninos. Deus nos guarde de leviandades". ${ }^{39}$

A demanda pelo federalismo materializou-se, como já discutimos anteriormente, através do Ato Adicional de 1834. Este extingue o poder moderador, cria e confere poderes significativos às Assembleias Provinciais e estabelece a figura do regente uno "eletivo e temporário" com mandato de quatro 
anos. A balança pendia, pois, para a federação, em detrimento do governo unitário, bem como acenava para a democracia, reversivamente ao autoritarismo do início do primeiro reinado em Pernambuco. Vencia, pois, a tese do "federalista de já e já".

\section{Manuseando a memória no "Vulcão da Anarquia"}

Ao longo de sua longa e prolífica existência, O Carapuceiro assistiu a duas interrupções em sua circulação. A primeira se estendeu entre os anos de 1835 e 1836, ao passo que a segunda verificou-se entre alguns meses de 1840 e 1841. Tais interrupções foram, todavia, abreviadas graças à impressão de artigos nas folhas do Diário de Pernambuco. Na prática, pois, a fábrica de carapuças jamais deixou de funcionar. Por um lado, a interrupção levada a efeito nos anos de 1835 e 1836 pode ter decorrido por conta da primeira eleição e investidura de Lopes Gama no cargo de deputado provincial. Ao mesmo tempo, em 1835, também estava atribuída ao Padre Carapuceiro a função de diretor do Colégio dos Órfãos do Recife, bem como do Curso de Jurídico de Olinda. Por outro lado, a interrupção de 1840 e 1841 decorreu do fato de Lopes Gama ter, então, assumido a cadeira de suplente como deputado geral do Império. Notamos que, para um jornalista costumbrista, avesso à política, nosso personagem descrevia trajetória oposta, à medida que ascendia a funções parlamentares, não apenas no âmbito da província, mas também ao nível do Estado imperial. Ademais, exercia cargos públicos na administração local, mormente ligados à educação, desde sua nomeação, em 1817, para o cargo de professor de retórica do Seminário de Olinda. Mas, acreditamos que foi sua popularidade à frente d'O Carapuceiro que o credenciara a investir na carreira parlamentar. ${ }^{40}$

Entre sua investidura no cargo de deputado provincial e seu primeiro retorno às lides jornalísticas, em 1837, a vida política do Império mudara significativamente. O tráfico de escravos, cujo fim deveria ter se dado em novembro de 1831, mantinha-se inalterado, e descrevia curva ascendente. Revoltas contrárias às políticas regenciais, urdidas às tramas políticas regionais que vinham se arrastando desde a independência na Bahia, Rio Grande do Sul, Pará e no Maranhão, explodiam sob a forma de movimentos políticos que, no limite, enveredavam pela secessão. O governo do regente Feijó, para o qual convergira parte significativa dos anseios federalistas antes represados, agonizava sob uma crise cujo único precedente parece ter sido a conjuntura da independência. $O$ próprio Feijó reconhece, em sua fala do trono de 1836, que "o vulcão da anarquia ameaça devorar o Império", e que era preciso que o parlamento lhe concedesse "leis adaptadas às necessidades públicas" e "força, com que possa fazer efetiva a vontade nacional". ${ }^{41}$ Os conservadores, na figura do pernambucano Araújo Lima, parecem, antes, capitalizar esse momento, e tomam as rédeas do país até o golpe da maioridade. Iniciava-se, assim, aquilo que os próprios contemporâneos tenderam a chamar de regresso.

As considerações a respeito da Confederação do Equador mudam de tom quando O Carapuceiro reaparece em 1837, após dois anos de interrupção. Em suas folhas não se falava mais em "restauração", nem tampouco em "federação", dois de seus temas centrais nos anos iniciais da regência. Tais conceitos são elididos do vocabulário político de Lopes Gama, desde então, em decorrência do desaparecimento de restauradores e do restauracionismo, uma vez que se suprimira seu fundamento político em setembro de 1834, com a morte de Dom Pedro I. A ideia de federação, por conseguinte, se extingue em seu discurso à medida que o federalismo pelo qual lutava Gama servia principalmente de corretivo às açôes e projetos políticos dos restauradores. A defesa da federação também definha em seus escritos, ademais, em decorrência do federalismo real e prevalecente, não apenas o do Ato Adicional de 1834, mas também o do Código de Processo Criminal, de 1832, das Assembleias Provinciais, do regente uno e da extinção do Conselho do Estado. Tal federalismo lhe parecia ter ido longe demais ao subtrair prerrogativas políticas do "Jovem Imperador". Por outro lado, se após 1837 O Carapuceiro silencia em relação à discussão acerca do federalismo, seu foco, agora, dirigia-se aos antimonarquismos, republicanismos e separatismos que, explícitos ou dissimulados, pairavam no ideário das principais revoltas e revoluções regenciais. ${ }^{42}$ 
Sem embargo, embora parecesse radical para um conservador como Lopes Gama, o federalismo real da década de 1830 não contemplou aspecto capital, presente na relação entre províncias e Estado unitário. A pouco notada lei de 24 de outubro de 1832, que orçava a receita e fixava a despesa para o ano financeiro de 1833 e 1834, e que se configurava como "lei de responsabilidade fiscal", estabelece regras que, daí por diante, limitam despesas e receitas do Estado imperial e, sobretudo, das províncias. ${ }^{43}$ Indiscutivelmente, ela pendia a favor do Estado unitário e em detrimento das províncias, tal a desproporção de fontes de receita ali previstas para o Império e o lacônico texto referente às fontes disponíveis para as unidades da federação. Destacamos, por exemplo, que a chamada "Receita Geral" compreendia, por exemplo, "direitos que se arrecadam nas Alfândegas, por importação, exportação, baldeação, e reexportação". Para um país majoritariamente agroexportador e escravista tais fontes de receita pareciam ser vitais para as províncias, mas elas eram açambarcadas pelo Estado unitário. Ademais, havia ainda outros 21 itens arrolados como "Receita Geral", isto é, que constituíam fontes de receita para o Estado imperial. Por sua vez, a "Receita Provincial" foi definida por exclusão: "Pertencem à receita provincial todos os impostos ora existentes não compreendidos na receita geral". Ademais, a lei fixou o montante que cada província dispunha para os gastos de sua administração, os quais incluíam despesas com "Guardas Policiais", "Catequese e civilização dos índios" e "Instrução pública", dentre outros itens. Desse modo, a lei de 1832 praticamente atravancou reforma tributária que permitiria às Assembleias Provinciais levar a efeito projetos inspirados nas prerrogativas que o Ato Adicional lhes concederia dois anos depois. À medida que engendrou a classificação das rendas em "provinciais" e "gerais", e que delegou ao governo imperial a partilha do montante de recursos gerados, as províncias viram obstaculizada sua pretendida autonomia. ${ }^{44}$

A Revolução Farroupilha (1835-1845), que eclodiu no extremo Sul do País, refletiu o descontentamento com este aspecto capital que a regência liberal anterior a 1837 não soubera contornar. A aliança de interesses entre pecuaristas e caudilhos daquela região, ambos desgostosos com a política imperial, revelava que, além de sofrer a concorrência do gado oriundo do Uruguai e das províncias vinculadas a Buenos Aires, a província meridional padecia com a asfixiante legislação fiscal do Império. Após vários desentendimentos e com o conflito armado já em curso, foi proclamada a República de Piratini em setembro de 1836 e, nessa circunstância, um caudilho local, o ex-prisioneiro político Bento Gonçalves, recém-fugido das masmorras da Bahia, foi eleito presidente. Os conceitos de federalismo e confederalismo, não apenas como eram discutidos no Brasil, mas, sobretudo, na região do Rio da Prata, galvanizaram a formação de partidos contrários que lutavam internamente pelo poder da província. Em 1845, após dez anos de guerra, surge, finalmente, acordo de paz entre rebeldes e o Império, bem como uma anistia geral. ${ }^{45}$

A Cabanagem (1834-1840), que se processou no outro extremo do país, na Província do Pará, começou, como sempre, como um conflito entre as elites locais contrárias e as favoráveis às políticas emanadas do Estado imperial, mas acabou congregando camadas mais baixas da sociedade e desenvolvendo uma trajetória de intensa violência entre proprietários e não proprietários, entre escravos e senhores. A origem de seus sucessivos líderes - Felix Antonio Malcher, Eduardo Angelim e Francisco Vinagre - refletiam o aprofundamento das tensões e a incorporação de setores populares e de seus interesses específicos ao movimento. No calor da guerra, uma república foi proclamada, a província foi, mais uma vez após a independência, desligada do Império, e seu presidente, bem como o governador de armas, foram assassinados. Após brutal repressão desencadeada pela regência, mormente ao longo do governo de Feijó, a qual resultou em aproximadamente 30.000 mortos, o Pará foi, mais uma vez, incorporado ao Império. ${ }^{46}$

A Sabinada (1837-1838), movimento urbano ocorrido na Cidade da Bahia, refletiu antiga dissidência, gestada havia quase duas décadas, entre liberais e conservadores baianos, a qual teve origem ao longo da guerra de independência (1822-1823). A revolta teve como principal líder o cirurgião Francisco Sabino Álvares da Rocha Vieira, donde advém o nome conferido ao movimento. De novembro de 1837 a março de 1838 a Cidade esteve sob o comando do governo revolucionário, mas sitiada por forças legalistas. Calcula-se que, após a incorporação daquele sítio ao controle da presidência da pro- 
víncia, havia aproximadamente 1.300 pessoas mortas e quase 3.000 presos políticos. Seis de seus líderes foram condenados à pena capital. ${ }^{47}$

Esse conjunto de eventos entrelaçados, aparentemente caótico e desordenado, mas dotado de notável coerência interna - marcada pela tensão entre federalismo e Estado unitário - causou profunda preocupação a Lopes Gama. Seu temor, explicitado nos escritos posteriores a 1837, era que eventos da mesma natureza e de mesmo furor incontrolável, mormente à medida que congregavam camadas populares, grassassem em Pernambuco. O passado recente da província, afinal, parecia habilitá-la para produzir tensões semelhantes. Em abril de 1838, em artigo intitulado "Triste fim da Sabinada”, vociferou contra os republicanos da Bahia, mas se dirigiu principalmente aos "Republiqueiros" pernambucanos, chamados de "Excelentíssimos Senhores Sabininhos, Sabinões de cá". Condenou-os por viverem em "lojas, boticas e botequins profetizando vantagens da República interina do seu irmão, e amigo Sabino". Acusava-os, enfim, de que "já contavam que a mesma cena se representasse em Pernambuco". Com ironia, Lopes Gama destratava não apenas a república e o republicanismo de Sabino, mas todo e qualquer republicanismo intentado no âmbito de seu idealizado império monárquico e constitucional:

Dizem que para sustentar uma República Democrática são precisas muitas virtudes no Povo. E por ventura faltam-nos virtudes republiqueiras? Quem sabe dar uma facadinha melhor do que nós? Quem nos levará as lampas em empolgar o alheio, e em esvaziar uma loja ou um armazém? Façamos a nossa República, que tudo irá bem. Imitemos o grande Sabino, que hoje é Ministro de Estado da Cidade da Bahia, e já governa bastantes Nagôs. ${ }^{48}$

Em outra alusão a Sabino, esta de fevereiro de 1838 - quando a Sabinada ainda seguia seu curso diz que "não nos faltam por cá Republiqueiros, que suspiram pela desordem, e muito desejariam, se efetuasse o mesmo fandango do Sabino, e companhia”. Nesta circunstância, ironiza, adverte e desautoriza aqueles pernambucanos que sentenciavam: "infalivelmente a República estreada em S. Pedro do Sul, no Pará, e agora na Bahia, lavrará como sarna por todo o Brasil”. Diz ainda Lopes Gama ironicamente, mas sem disfarçar seu temor, que "aqui não tarda que arrebente também a revolução Republiqueira, capitaneada por Manê Côco, por Chico Piegas, Totonio Patusco, Quimquim Gostoso, Cazuza Candeira, e outros sabinos ejusdem furfuris". ${ }^{49}$ Lopes Gama comemorou efusivamente nos primeiros meses de 1839 aquilo que chamou de "triunfo da legalidade na Bahia":

Temos passado o ano de 1838 memorável pelo triunfo que obteve a Legalidade na Bahia, onde o espírito republiqueiro ousou levantar o colo, produzindo naquela grande Província horrores incalculáveis. Desde o roubo até o assassínio, desde o assassínio até o incêndio, desde o incêndio até o sacrilégio tudo se perpetrou sob o domínio desses homens loucos, ou ambiciosos, que conceberam o pensamento de estabelecer uma República provisória na Bahia durante a menoridade do Imperador, depois da qual tornariam as cousas ao antigo estado, volvendo à Monarquia Representativa! ${ }^{50}$

Seu ataque mais visceral, contudo, foi dirigido contra os rio-grandenses. Em dezembro de 1837, em artigo escrito sob o título "Reflexões acerca da República Palhaça de Piratini”, afirma que se revoluções como a do Rio Grande continuassem a se repetir, todo o Brasil seria dilacerado na "voragem do roubo, da carnificina, e dos maiores horrores da guerra civil". Em outro artigo publicado naquele mesmo mês, Lopes Gama lamenta a sorte do povo comum do Rio Grande, acusando, por outro lado, as classes altas da província de manipulá-las em benefício próprio: "que roubos, que violências, que mortandade, que estragos, que horrores, por que tem passado esse povo! E a quem são devidos esses males? A uma dúzia de espertalhões especuladores políticos, que querem ser grandes, ricos e poderosos". ${ }^{51}$ Em inícios de 1838, todavia, Lopes Gama procura dar nomes aos bois, acusando, ademais, possível cooperação de repúblicas vizinhas ao movimento gaúcho:

O Rio Grande do Sul lá está despedaçado por Bento Gonçalves, e seus sequazes, que querem à força enxertar a sua Democracia nessa desgraçada Província; e apesar dos sinceros esforços do Governo, ainda não foi 
possível acabar com esses revolucionários que mui provavelmente contam com o auxílio de seus vizinhos. Mas é muito de esperar que as forças e meios postos à disposição da Legalidade por último triunfem, e chamem ao grêmio da Grande Família Brasileira a essa porção iludida, e desvairada. ${ }^{52}$

Nessa nova conjuntura de federalismos revolucionários e, no limite, republicanos, cabia, pois, reelaborar a memória da Revolução de 1817 e, principalmente, da Confederação do Equador expurgando a ideia de "boas intençôes dos patriotas de 24", como escrevia Lopes Gama em agosto de 1833. Importava agora deixar de lado aquelas "boas intenções" e desqualificar esse evento de forma categórica. A operação mental de criação da contra-memória baseia-se, desde então, em alguns topoi centrais.

O primeiro deles é a qualificação desses eventos como "quixotescos", isto é, como aventuras desmedidas que acabaram tragicamente. Os ex-rebeldes são, assim, descritos, ou como "quixotes", ou como meros oportunistas. Ademais, os líderes de 1817, ou confederados do Equador, são apresentados como loucos, quiméricos e fantasiosos. Assim, pois, Lopes Gama ressalta, nesses anos finais da década de 1830, como alguns pernambucanos sonhavam com a possibilidade de Bento Gonçalves desembarcar na província para fazê-la abraçar a "sagrada causa dos farrapos". Ao mesmo tempo, lembra, jocosamente, que em 1824, durante a "Quixotal Confederação do Equador", houve quem acreditasse que o General Bolívar viria em socorro dos revolucionários das províncias do Norte. Diz o Padre Carapuceiro que, naquele tempo, "até houve quem visse a guarda avançada já de caminho, nas cabeceiras do nosso Rio de S. Francisco”. Por esses mesmos anos, Lopes Gama sustentou que "Pernambuco de 1838 já não é o mesmo Pernambuco de 1824, em que houve gente tão papalva, que pegou na isca da Confederação do Equador". Em artigo intitulado "O espírito da ordem em Pernambuco", publicado em agosto de 1839, sustentou que esta província “já louqueou bastante”, porém "graças a Providência passou essa febre revolucionária”. Aduz, ademais, que Pernambuco, então, podia desenvolver a indústria, o comércio e as artes, devido à duradoura paz, e que o mesmo não acontecia no Pará, na Bahia e no Rio Grande do Sul, províncias que se encontravam em "lastimoso estado" devido ao "facho da guerra civil". "São incalculáveis" - diz ele - "os benefícios que uma paz duradoura acarreta a qualquer país". Assim, citou quatro projetos em andamento em Pernambuco que só poderiam ser colocados em pauta devido ao "espírito de ordem": o encanamento de água potável, a construção de um novo teatro, a iluminação a gás e a construção de pontes de ferro. ${ }^{53}$

Um segundo tópos presente no discurso de Lopes Gama, referente à construção de contra-memória da Revolução de 1817 e da Confederação do Equador, consiste na desqualificação de seus personagens e de suas trajetórias posteriores àquele evento. Em artigo de fevereiro de 1838, por exemplo, faz clara alusão aos revolucionários de 1824, ao afirmar que "devotos de Sabino", na província da Bahia, também chamados de "saltimbancos republiqueiros", depois de "acabada a tragédia", fugiriam para a "piscina dos Estados Unidos" - como fizeram alguns pernambucanos na década anterior, a exemplo de Natividade Saldanha, Cabugá e Emiliano Benício Mundurucu. ${ }^{54}$ Em outro artigo, este de dezembro de 1837, quando a Sabinada ainda seguia seu curso, faz outra referência implícita, mas facilmente captada nas entrelinhas, aos ex-rebeldes pernambucanos que se refugiaram no exterior:

Os mantenedores da desordem, embaindo o crédulo povo com promessas de grandes felicidades, e ao mesmo passo dando todo o poderio a canalha, aos malfeitores, \&c. para sustentarem a tal câmara óptica de República, não se descuidariam de ir enfardelando o que pudessem, prontos a qualquer contratempo para pôr os pés em polvorosa; quem escamogindo-se para o Merca-tudo (os Estados Unidos) quem para Londres, quem para Paris, onde iriam desfrutar o que empolgaram, e rir dos tolinhos, que nele se fiaram, e cá ficam chorando a sua desgraça, a de sua família, etc. ${ }^{55}$

Há aí referências explícitas a Manuel Carvalho Paes de Andrade, presidente da Confederação do Equador e seu principal mentor político e intelectual mediante a redação de seus famosos manifestos. ${ }^{56}$ Este, graças à sua fortuna pessoal, acumulada principalmente no comércio de grosso trato, se exilou em Londres ao final do evento - ao mesmo tempo em que o combatente Frei Caneca ou o "preto" Agos- 
tinho Bezerra Cavalcanti eram executados pelas forças imperiais. Paes de Andrade retornou com força ao cenário político provincial, após a abdicação, posto que a partir de 1833 elegera-se para os cargos de deputado provincial por Pernambuco e senador do Império pela Paraíba, tornando-se, finalmente, presidente da província de Pernambuco em 1834. A partir de 1836, exerceu cargo de senador do Império e em 1840 foi um dos mais ativos partícipes do grupo que perpetrou o chamado "golpe da maioridade". Assim, pois, o revolucionário que outrora se empenhara em rebelar-se contra os reis adere ao projeto aparentemente "regressista" que entronizou o jovem D. Pedro II com apenas 15 anos de idade; fazia-o, contudo, como maneira de suprimir o governo conservador do também pernambucano Araújo Lima, então regente do Império. ${ }^{57}$

Lopes Gama certamente se referia a Paes da Andrade quando elaborou, em dezembro de 1837, caricatura de personagem que, amestrado "na lição dos furiosos filosofantes do século passado", diz não haver "Príncipe, Rei, Imperador que prestem para nada". Segundo o Padre Carapuceiro, este tipo de gente só queria "República e mais República", e "outra forma de Governo" seria "um crime de lesa humanidade”. E continua descrevendo o personagem:

... arranjai um empregozinho a um desse Catôes de botequim, tornai filho da folha a esse filho das ervas, e da Democracia; e vereis que espantosa conversão! O homem vivia esfomeado por uma rusga; agora, porém, já é amigo da ordem; estava disposto a plantar uma Republicazinha até no seu quintal entre um pato, duas galinhas, e uma bacorinha tísica; mas hoje já se deixou dessas cousas, hoje é legalista, e talvez até propugne pelo Regresso. E hei de fiar-me em tais badamecos? Hei de acreditar nos Republiqueiros do meu país? ${ }^{58}$

Interessante observar que o presidente da Confederação e o Padre Carapuceiro chegaram a se desentender publicamente em 1835. Neste ano, isto é, ao longo da presidência de Paes de Andrade na província de Pernambuco, Lopes Gama exercia, como vimos, a função de diretor do Colégio dos Órfãos do Recife. Nesta condição, solicita ao governo provincial mais recursos para a manutenção da instituição. Paes de Andrade, por seu turno, não apenas nega-lhe verbas, como o acusa publicamente de má gestão das que lhe eram destinadas. A pecha de "quixotesco", atribuída a ele e à Confederação do Equador que liderara dez anos antes, então amplamente difundida através de $O$ Carapuceiro, certamente influíra na decisão do presidente de cercear recursos à administração do Colégio dos Órfãos. ${ }^{59}$ Assim, ao colocar em ridículo os protagonistas de 1824, Lopes Gama cumpria dois desideratos. Por um lado, procurava frear e pôr sob suspeita quaisquer atitudes de potenciais revolucionários no âmbito das regências. Por outro lado, ele desqualificava antigos oponentes que, após a abdicação, ressurgiram na arena política. Estes, ademais, poderiam insuflar a tão temida revolução, ou simplesmente continuá-la. Era preciso pôr freios ao carro.

Parece importante, para concluir esta discussão, observarmos que ao menos um dos personagens de 1817 e 1824 fora poupado por Lopes Gama. Referimo-nos a Frei Joaquim do Amor Divino Caneca (1779-1825). Ainda na primeira fase d'O Carapuceiro (1832-1834), marcada pelo ataque aos restauradores e pela defesa do sistema federativo, Gama publica artigo no qual relata um suposto sonho. Neste desvela-se "figura veneranda que bem parecia já não pertencer à mortalidade, e afecções terrenas". Tal figura trazia numa das mãos "as mais lindas flores"; na outra, carregava um livro. Uma coroa pendia de sua cabeça. Lopes Gama não conseguiu a princípio reconhecer quem era essa misteriosa pessoa, mas em seguida esta se identificou: "Eu sou o invicto Caneca; eu sou aquele Pernambucano, que sempre avesso aos tiranos, em público patíbulo expiei o crime de amar muito a minha pátria". ${ }^{60}$

Em seguida, Caneca, como por mágica, coloca frente aos olhos de Lopes Gama visão de como seria a "sanguinolenta catástrofe da restauração". Havia um trono sobre um "montão de sangrentos cadáveres", no qual estava "assentado, empunhando o cetro, o monstro Bragantino, que se não saciava de vítimas". As ruas estavam desertas, e era possível ouvir "o som dos campanários, que anunciavam aos poucos vivos a morte desastrosa dos seus concidadãos". Havia também "cadafalsos alterosos levantados em todos os bairros”. Lopes Gama, observando horroroso cenário, questionou: 
Quem é aquele militar brioso que com as mãos atadas, com grosseiro laço ao pescoço, caminha com tardo pé ao medonho lugar do suplício? Quem é aquele Sacerdote pacífico, que degradado das vestes Pontifícias, e das sagradas ordens, como se fora um perverso, qual humilde cordeiro, vai por força ao matadouro? Quem é aquele Pastor venerando, que atado pelo gasnate vai tirado a cauda um cavalo? Aqui, com o rosto ensanguentado vai beijando o pó da terra, ali procura erguer-se, e cambaleia, acolá recebe insultos, apupos, e pedradas da ínfima canalha de ambos os mundos? Ah! (diz-me o gênio Pernambucano enternecido) são todos Brasileiros; são cidadãos livres, q’ por inexperientes, e desunidos não poderão resistir, e fazer face a volta do Lusitano de Bragança. ${ }^{61}$

Personagem poupado por Lopes Gama, a memória de frei Caneca era, na fase inicial do jornal, bandeira importante na luta contra os restauradores. Por outro lado, ele era apresentado como mártir, e não como aproveitador ou mero oportunista, como lhe parecia a caleidoscópica trajetória política de Paes de Andrade. Finalmente, Caneca, uma figura das revoluçôes de 1817 e 1824 a merecer algum respeito na pena do Gama, aparece aqui como mártir, não do Brasil, mas, de Pernambuco. A pátria pela qual morrera fora a pernambucana, uma das poucas no império nascente a manifestar-se contra o, agora, "tirano Lusitano de Bragança”. No entanto, dentro do vocabulário político de Lopes Gama, como veremos a seguir, a noção de pátria acenava para outra direção em fins do período regencial.

\section{Pátria, nação e país}

A defesa da unidade do Império, da monarquia constitucional e do Estado unitário levada a efeito por Lopes Gama, ao longo do período regencial, sobretudo a partir de 1837, constituíram, como vimos, topoi recorrentes em seu discurso. Para dar fundamento a esses temas, tão veementemente associados pela historiografia à elite saquarema, redefiniu certos vocábulos políticos, como os de pátria, nação e país. Sua intenção, ao forjar novos conteúdos para tais conceitos, era, por um lado, combater seus inimigos separatistas, republicanos e federalistas do presente, encarnados nos revolucionários baianos, gaúchos e paraenses, e, por outro lado, sepultar a memória de seus inimigos do passado: os revolucionários de 1817 e, principalmente, os "federalistas do equador".

$\mathrm{Na}$ análise empreendida por Márcia R. Berbel acerca do vocabulário político à época das cortes constituintes de Lisboa (1821-1822) e da própria independência, três categorias são examinadas em pormenor: pátria, nação e país. Pátria, para os deputados baianos, pernambucanos ou paulistas presentes às cortes lisbonenses seria seu lugar de origem ou nascimento. Este, contudo, não era o Brasil, e sim a comunidade que os elegeu, isto é, sua província. A nação da qual esses deputados se sentiam parte não era outra senão a portuguesa. O Brasil, à época da independência, se enquadraria no conceito de país, ou seja, um vasto território carente de identidade política. Apenas uma porção geográfica específica, quase assemelhada à de continente, e nada mais. Assim, segundo o discurso desses deputados, Bahia, Pernambuco ou São Paulo seriam suas pátrias, isto é, espaços dotados de identidades coletivas a que se devotavam sentimentos profundos e lealdade política. O Brasil, por seu turno, era seu pais, e como tal representava apenas um vasto continente. O Reino de Portugal, Brasil e Algarves, uma formação nacional atlântica nascida em 1815, eivada de ramificaçôes na Ásia e na África, era, por fim, sua nação. Era este último conceito que, à época, aparecia como o mais importante e central no imaginário político. ${ }^{62}$ Sentimento semelhante foi partilhado, quase dez anos antes, nas Cortes de Cádiz (1810-1814). Também ali havia representantes de "ambos os hemisférios", isto é, da América e da Europa, e o Reino da Espanha, incluindo seus vice-reinados, audiências e capitanias gerais americanas, constituíam partes da mesma "nação espanhola". ${ }^{3}$

No entanto, houve uma virada na utilização dos conceitos de pátria, nação e país em meados da década de 1830, aspecto claramente perceptível em O Carapuceiro. Em seus artigos percebe-se que aqueles conceitos possuem distinta aplicação, posto que sua representação era, agora, o Império do Brasil e suas distintas províncias. Em artigo publicado em maio de 1839, intitulado "O Bairrismo", Lopes 
Gama propôs formas de auxiliar na manutenção da unidade do Império. Dissertou sobre um vocábulo que não era contemplado pelos dicionários, mas que todos sabiam o que significava. Definiu o "bairrismo" como "o excessivo amor, a indiscreta predileção pelas cousas, e pessoas da localidade em que nascemos". Era a pátria e o patriotismo de outrora travestidos em entidade e sentimento piegas. Ademais, eram entidade e sentimento tingidos de negatividade, haja vista seu potencial de perigo, desordem e ameaça à unidade da "nação". Para o Padre Carapuceiro, o "bairrismo" era um "vício que nos pode levar às mais terríveis desgraças":

Esta paixão vil, baixa, e ignominiosa não deve ser confundida com o nobre amor da Pátria, amor, que quando bem regulado, é o manancial das mais heróicas virtudes. A nossa Pátria, pois, é o Brasil, e todos os Brasileiros constituem uma só, e a mesma família. ${ }^{64}$

Na década de 1830, Lopes Gama, criticava, portanto, a antiga "pátria" e o "patriotismo" da era da independência ou, antes, redefinia essas noçōes. O vocábulo "pátria" e a qualidade de ser "patriota" eram referências ao Brasil, à sua unidade territorial, ao seu Estado unitário e imperial, e não ao local de nascimento, ou seja, às províncias. Lopes Gama evocou, assim, uma identidade nacional, caracterizando-a como o "manancial das heróicas virtudes". O contrário disso, o "bairrismo", era um vício. Quando qualificou o "bairrismo" como "paixão vil", se voltou, no presente, contra a exacerbação das identidades regionais, então em voga, no âmbito da Sabinada, da Revolução Farroupilha ou da Cabanagem. Formulou, assim, ideia de identidade brasileira a qual deveria estar sempre acima de todas as demais identidades regionais. A identidade nacional, nos seus termos, sobrepor-se-ia à identidade regional e o "amor à pátria" deveria superar o "infernal bairrismo", de modo a este não desunir a "Grande Família Brasileira”. A contra-memória da Revolução de 1817 e, principalmente, da Confederação do Equador, por ele forjada ao longo da década de 1830, com seus topoi do "quixotismo" e da desqualificação da trajetória individual de seus participantes, incluía, retroativamente, a mácula do bairrismo, atribuída aos revolucionários, federalistas e separatistas do presente e do passado. ${ }^{65}$

\section{Epílogo}

Até sua morte, em 1852, Lopes Gama alimentou a contra-memória da Revolução de 1817 e da Confederação do Equador que elaborara ao longo das regências. Em novo jornal por ele publicado nos albores do segundo reinado, O Sete de Setembro (1845-1846), ${ }^{66}$ ainda se referia ao movimento de 1824, por exemplo, como "quixotal revolta republiqueira" ${ }^{67}$ No entanto, a partir da década de 1840, outra memória daquele movimento, bem como da revolução de 1817, começa a tomar corpo. Esta, em breve tempo, como se verá adiante, se tornaria hegemônica, solapando o alcance e a longevidade da contramemória construída em O Carapuceiro. Ao início do Segundo Reinado, esta memória não possuía os contornos ideológicos e a configuração identitária que ganharia mais tarde, contando, para sua disseminação, inclusive, com apoio do governo provincial. Antes, ela ainda parecia marcar compasso no bojo dos conflitos da década de 1840, marcada pela ascensão liberal e popular do movimento praieiro.

A primeira publicação de peso, em favor dos movimentos políticos do primeiro quartel do século XIX, surgiu em 1840. Trata-se de História da revolução pernambucana em 1817, de Francisco Muniz Tavares. O autor fora militante de 1817 e, depois de ter sido preso político na Bahia como decorrência da repressão a esse movimento, tornara-se deputado constituinte em Lisboa e, após a independência, no Rio de Janeiro. Depois dos turbulentos anos das regências, monsenhor Muniz Tavares volta à cena política elegendo-se deputado geral pela província de Pernambuco (1845-1847). Também por esses anos ocupa altos cargos civis e eclesiásticos, tanto em Pernambuco, como na Corte e no exterior. À época da publicação de sua obra, procura tomar distância dos grupos políticos provinciais, tanto do bando liberal como daquele declaradamente conservador e Cavalcanti. Daí, pois, que sua História, embora não renegasse o passado provincial, ou sua trajetória pessoal, procurava não confrontar com o poder estabe- 
lecido no Rio de Janeiro. Antes, Tavares sempre fora agraciado com honrarias na capital do Império, a exemplo dos títulos da Imperial Ordem do Cruzeiro (1822), da comenda da Ordem de Cristo (1858) e, finalmente, da Imperial Ordem da Rosa (1860). Ainda no primeiro reinado, fora nomeado secretário da legação brasileira em Roma (1826-1832), bem como se tornara Conselheiro de Estado, por carta imperial de 9 de fevereiro de $1847 . .^{68}$

No entanto, o monsenhor era defensor apaixonado da ideia de que cabia à geração de 1817 lugar central no panteão da independência brasileira: "A revolução de Pernambuco em 1817, bem que mui pouco durasse, fará sempre época nos anais do Brasil; tempo virá talvez em que o dia 6 de março, no qual ela foi efetuada, será para todos os Brasileiros um dia de festa nacional". Ademais, Tavares procura realçar que o fracasso da revolução decorrera não apenas da "divergência das províncias brasileiras", frequentemente acusadas, nativisticamente, de fazer malograr "os nobres esforços dos pernambucanos". Também ressalta, apartidariamente, os "vários erros daqueles que se puseram à sua frente: tais erros são do domínio da história; é indispensável divulgá-los para lição da posteridade; o mal não cura-se sem ser conhecido". Apesar de tais ressalvas, sua obra foi duramente criticada por historiadores fluminenses, como Pereira da Silva e Varnhagen, unidos em torno da ideologia imperial e unitária do Instituto Histórico e Geográfico Brasileiro, fundado em 1838. ${ }^{69}$

Posteriormente, veio a lume outra obra alusiva ao evento de 1817, esta francamente favorável ao partido republicano e separatista da província. Referimo-nos a Os mártires pernambucanos vítimas da liberdade nas duas revoluçôes intentadas em 1710 e 1817, a qual embora tivesse sido escrita em 1823, como informa seu autor, Padre Joaquim Dias Martins, só é publicada 30 anos depois, isto é, em 1853. Este pequeno dicionário biográfico, visivelmente antilusitano - visto que se baseia em suposto vínculo entre revoltas pernambucanas e antiportuguesas dos séculos XVIII e XIX - não tinha como ser publicado nos anos iniciais do primeiro reinado, por razôes óbvias. Precisou, pois, esperar pelo término do longo período de lutas políticas encerrado pela Praieira (1848-1849), bem como pelo surgimento do gabinete da Conciliação (1853-1856), para chegar às mãos de público, esquecido das contendas políticas da primeira metade do século XIX. Coube a Filipe Lopes Neto conservar e depois publicar o manuscrito de Dias Martins, dando notícia de que o tinha à venda "no Pátio do Colégio, oficina de encadernação", através do Diário de Pernambuco, a 31 de outubro de $1853 .{ }^{70}$

A década de 1850 assinala, pois, viragem definitiva da contra-memória elaborada por Lopes Gama em torno das revoluções de 1817 e 1824 . O malogro definitivo da visão quixotesca, agora convertida em leitura heróica e regional da história nacional, dá-se, por um lado, mediante o concurso do comendador Antonio Joaquim de Mello (1794-1873), e por outro lado, através da criação do Instituto Arqueológico e Geográfico Pernambucano (1862), cujo primeiro presidente foi monsenhor Muniz Tavares (1862-1874).

Coube a Antonio Joaquim de Mello escrever, em forma de biografias, a história da província desde a perspectiva do grupo federalista, no qual havia militado em 1817 e 1824 . Encarcerado em pelo menos duas circunstâncias (1818 e 1828-1829), exercera desde 1823 diversos cargos políticos e administrativos: vereador da Câmara do Recife, deputado provincial, deputado geral e presidente da província da Paraíba. Por cinco vezes, entre 1837 e 1850, obteve votos suficientes para figurar na lista sêxtupla da província de Pernambuco ao senado. Jamais foi escolhido. Sua estratégia memorialística consistiu em elaborar projeto para o governo da província intitulado "Biografias de alguns pernambucanos ilustres", o qual foi aprovado por parecer datado de 29 de outubro de 1868. Da comissão que elaborara o parecer, fazia parte Muniz Tavares. Graças à modesta dotação que lhe foi concedida, Antonio Joaquim de Mello pode passar em revista a memória de 1817 e 1824 elaborando biografias, algumas publicadas postumamente. Dentre estas se destacam as dedicadas a Frei Caneca, ativo em 1817, ideólogo e combatente em 1824; a Gervásio Pires Ferreira, militante de 1817 e presidente da primeira Junta de Governo da província (1821-1822); e a José da Natividade Saldanha, mulato formado em Coimbra que se convertera em ideólogo e secretário de governo ao tempo da Confederação do Equador. ${ }^{71}$ 
Finalmente, a criação do Instituto Arqueológico e Geográfico Pernambucano (IAGP), em janeiro de 1862, sela definitivamente a opção da intelligentsia da província de criar uma contra-memória acerca da formação do Estado e da nação no Brasil - o que equivalia a resgatar do opróbrio os "quixotes" de 1817 e 1824. Graças a esta operação institucionaliza-se a tarefa de narrar a história nacional desde a perspectiva provincial, escrevendo-a a contrapelo da memória forjada pelos intelectuais da corte. Para além das várias propostas de reunião de criação de institutos históricos surgidas desde a década de 1830 , houve, efetivamente, dois impulsos fundamentais ao movimento de fundação do IAGP. Por um lado, parece ter mexido com brios pernambucanos as visitas ao Recife do imperador Pedro II, em 1859, e de Varnhagen, em 1861. Ambos assinalaram o descaso para com monumentos, documentos e conhecimentos disponíveis acerca do passado regional. ${ }^{72}$

Por outro lado, o IAGP tinha como principal objetivo antepor-se às constantes solicitações e demandas por documentos civis e eclesiásticos emanados pelo "Arquivo Público do Rio de Janeiro", ou pelo "Arquivo Público do Império", tais como as que se leem no Diário de Pernambuco de 18 de janeiro de 1845 e 23 de janeiro de 1853. Tais ordens amparavam-se no Regulamento no 2, de 2 de janeiro de 1838, o qual dava "instruções sobre o Arquivo Público provisoriamente estabelecido na Secretaria d'Estado dos Negócios do Império”. Proposto por Bernardo Pereira de Vasconcelos e Pedro de Araújo Lima, então baluartes do regresso conservador, o abrangente regulamento tendia a subtrair das províncias documentos civis e eclesiásticos, os quais, a partir de então, deveriam ser remetidos à Corte. Pari passu à criação do Arquivo Público do Império, a fundação do IHGB em outubro daquele mesmo ano consolidava o projeto de elaboração de "história nacional" cujo desfecho era o processo de construção e enraizamento social do Estado unitário sediado no Rio de Janeiro.

Não por acaso, na reunião do dia 3 de agosto de 1865, os membros do IAGP discutiram a indicação, realizada "por intermédio da Presidência da Província", de se solicitar ao "Governo Imperial a permissão de ser arquivada neste Instituto a devassa a que se procedeu por ocasião da revolução de 1817 em Pernambuco, como um monumento histórico, que muito enriquecerá nosso arquivo”. Naquela ocasião, tal "indicação" foi lida e "aprovada sem discussão" pelos presentes. ${ }^{73}$ Não se tratava, em absoluto, de confrontar politicamente o Estado imperial, e muito menos abrir, mediante escavação da memória, feridas não de todo cicatrizadas. Não se partia, pois, para um confronto político, nem aberto, nem velado, apenas encaminhava-se demanda em torno do manuseio da memória. Esta, se não era operação central para os membros do Instituto, dizia muito acerca de sua identidade como grupo social, e de suas origens na vida pública do Império. Eles não expressavam tal demanda em termos de ideais políticos abstratos, e revelavam sentimentos e pensamentos que longe estavam de culminar em ação política concreta. ${ }^{74}$ A trajetória de seus integrantes - a exemplo de Muniz Tavares, que presidiu aquela sessão - é eloquente. Àquele momento havia pouco interesse de sua parte por política partidária e, antes, é notório seu isolamento por esses anos, como relatam seus biógrafos. O IAGP constituía, pois, instituição distante da arena de disputas, conflitos e tensões frequentemente chamada de política. Desde então, e até as comemorações oficiais dos centenários da revolução de 1817 e, em 1924, da Confederação do Equador, que premiou "trabalhos históricos" sobre este evento, ${ }^{75}$ a visão quixotesca daqueles movimentos havia se extraviado para sempre.

\section{Notas}

${ }^{1}$ Para uma visão de conjunto do período regencial, com ênfase não em sua suposta anomia, mas nas perspectivas estruturais que lhe conferem sentido e coerência, ver o ensaio de MOREL, Marco. O período das regências (1831-1840). Rio de Janeiro: Jorge Zahar Editor, 2003.

${ }^{2}$ Sobre a noção de espaço público no período regencial e sobre a grande quantidade de periódicos que circularam por aqueles anos, ver os estudos de MOREL, Marco. As transformaçôes dos espaços públicos. Imprensa, atores políticos e sociabilidades na cidade imperial (1820-1840). São Paulo: Hucitec, 2005.

${ }^{3}$ Cf. COSTA, F. A. Pereira da. Dicionário biográfico de pernambucanos célebres. Recife: Tipografia Universal, 1882, p. 724. 
${ }^{4}$ Cf. MELLO, Evaldo Cabral de (Org.). O Carapuceiro: crônicas de costumes. São Paulo: Cia. das Letras, 1996.

${ }^{5}$ Sobre a circulação de $O$ Carapuceiro pelas províncias do Império ver o ensaio de PALLARES-BURKE, Maria Lúcia Garcia. Nísia Floresta, O Carapuceiro e outros ensaios de tradução cultural. São Paulo: Hucitec, 1996. Para uma comparação entre $O$ Carapuceiro e outros periódicos publicados no Império e em Pernambuco ao longo do século XIX, ver os trabalhos de NASCIMENTO, Luis do. História da imprensa de Pernambuco (1821-1954). Vol. IV. Recife: Editora Universitária, 1969 e CARVALHO, Alfredo de. Annaes da imprensa periódica pernambucana de 1821 a 1908. Recife: Tipografia do Jornal do Recife, 1908.

${ }^{6}$ Cf. SILVA, Luiz Geraldo. Um projeto para a nação. Tensōes e intenções políticas nas "Províncias do Norte". Revista de História (USP). Vol. 158, $1^{\circ}$ sem. de 2008, p. 199-216; BERNARDES, Denis A. de M. Pernambuco e o Império (1822-1824): sem constituição soberana não há união. In: JANCSÓ, István (Org.). Brasil: formação do Estado e da nação. São Paulo/Injuí: Hucitec/Unijuí, 2003, p. 219-249.

${ }^{7}$ Desde o século XIX, O Carapuceiro vem sendo visto como um periódico essencialmente costumbrista. Partilham essa interpretação, entre outros, COSTA, F. A. Pereira da. Dicionário biográfico de pernambucanos célebres, op. cit., p. 726-727; COSTA, F. A. Pereira da. Vocabulário pernambucano. Recife: Editora do Brasil, 1976 [1908]; CASCUDO, Luiz da Câmara. Dicionário do folclore brasileiro. São Paulo: Global, 2003; FREYRE, Gilberto. Um ortodoxo brasileiro do século XIX. Jornal do Comércio. Recife, 17 de setembro de 1942; FREYRE, Gilberto. Casa grande e senzala. Rio de Janeiro: José Olympio, 1951 [1933]; VALENTE, Waldemar. O Padre Carapuceiro: crítica de costumes na primeira metade do século XIX. Recife: Departamento de Cultura da Secretaria de Educação e Cultura, 1969; DANTAS, Leonardo. Prefácio. In: GAMA, Miguel do Sacramento Lopes. O Carapuceiro. Edição fac-similar da coleção do jornal (1832-1842). Recife: Fundação de Cultura Cidade do Recife, 1983; MELLO, Evaldo Cabral de (Org.). O Carapuceiro: crônicas de costumes, op. cit.; MELLO, José Antonio Gonsalves de. Diário de Pernambuco. Economia e Sociedade no 2º. Reinado. Recife: Editora Universitária da UFPE, 1996.

${ }^{8}$ Cf. O Carapuceiro, $\mathrm{n}^{\circ} 21(21 / 06 / 1834)$.

${ }^{9}$ Cf. BARATA, Cipriano. Sentinela da Liberdade e outros escritos (1821-1835). Organização e edição de Marco Morel. São Paulo: Edusp, 2008, p. 871-876.

${ }^{10} \mathrm{Na}$ verdade, como bem notou Marco Morel, o Sentinela da Liberdade na sua Primeira Guarita, a de Pernambuco, onde Hoje Brada Alerta!! que publicara o artigo crítico a $O$ Carapuceiro era o de número $1^{\circ}$, e não número $2^{\circ}$, como escreveu Lopes Gama. Cf. BARATA, Cipriano. Sentinela da Liberdade e outros escritos (1821-1835), op. cit., p. 872, nota 3.

${ }^{11}$ Cf. O Carapuceiro, no 26 (29/07/1834).

${ }^{12}$ Cf. FELDMAN, Ariel. O império das carapuças: espaço público e periodismo político no tempo das regências (18311842). Dissertação de Mestrado apresentada ao Programa de Pós-Graduação em História da UFPR. Curitiba, 2006.

${ }^{13}$ Cf. MELLO, Evaldo Cabral de. A outra independência: o federalismo pernambucano de 1817 a 1824 . São Paulo: Ed. 34, 2004; DOLHNIKOFF, Miriam. O pacto imperial: origens do federalismo no Brasil. São Paulo: Globo, 2005; DOLHNIKOFF, Miriam. Elites regionais e a construção do Estado nacional. In: JANCSÓ, István (Org.). Brasil: formação do Estado $e$ da nação, op. cit., p. 431-468; as questōes das relaçōes entre "centralização" e "descentralização" no Império já haviam sido postas há décadas, mas com enfoque diverso, por CARVALHO, José Murilo. A construção da ordem: a elite política imperial. Teatro de sombras: a política imperial. Rio de Janeiro: Editora da UFRJ/Relume Dumará, 1996, p. 181-208.

${ }^{14}$ Cf. MOREL, Marco. As transformaçôes dos espaços públicos, op. cit., p. 140.

${ }^{15}$ Cf. ANDRADE, Manuel Correia de. A Guerra dos Cabanos. Recife: Editora Conquista, s.d., p. 31, 163-203.

${ }^{16}$ Cf. FELDMAN, Ariel. Conciliar a nação: a divisão dos poderes em debate na imprensa pernambucana (1822-1824). Anais do XIX Encontro Regional de História da ANPUH. São Paulo: ANPUH/Seção São Paulo, 2008; LEME, Mariza Saez. Dissidências regionais e articulações nacionais nos projetos de independência: o Conciliador Nacional em Pernambuco. Anais do XXIV Simpósio Nacional de História. São Leopoldo: Unisinos, 2007.

${ }^{17}$ Cf. FELDMAN, Ariel. Uma crítica às instituiçōes representativas do período das regências (1832-1840). Almanack Braziliense, no 4, nov., 2006, p. 65-81.

${ }^{18}$ Cf. Lei no 16 , de 12 de agosto de 1834. Faz algumas alterações e adições à Constituição Política do Império, nos termos da Lei de 12 de outubro de 1832. Coleção das Leis do Império do Brasil (1834, segunda parte). Rio de Janeiro: Typographia Nacional, 1866, p. 15-22.

${ }^{19}$ Cf. CARVALHO, José Murilo de. A construção da ordem. op. cit.; MATTOS, Ilmar R. Tempo saquarema. A formação do Estado Imperial. São Paulo: Hucitec, 1990. Uma crítica a essas posições pode ser lida em DOLHNIKOFF, Miriam. O pacto imperial, op. cit.. A autora acredita que as reformas descentralizadoras da regência promoveram um "pacto federativo" que o regresso conservador não conseguiu anular. Sobre este aspecto, ver também DOLHNIKOFF, Miriam. Elites regionais e a construção do Estado nacional, op. cit.

${ }^{20}$ Cf. Lei de 12 de maio de 1840. Interpreta alguns artigos da Reforma Constitucional. Coleção das Leis do Império do Brasil de 1840 (Tomo III, parte I). Rio de Janeiro: Typographia Nacional, 1863, p. 5-7. 
${ }^{21}$ A "historiografia saquarema" é definida por Evaldo Cabral de Mello como "a historiografia da corte fluminense e dos seus epígonos na República, para quem a história da nossa emancipação política reduz-se à da construção do Estado unitário. Nesta perspectiva apologética, a unidade do Brasil foi concebida e realizada por alguns indivíduos dotados de grande descortino político, que tiveram a felicidade de nascer no triângulo Rio-São Paulo-Minas e a quem a pátria ficou devendo o haverem-na salvo da voracidade dos interesses provinciais, como se estes fossem por definição ilegítimos, e do gosto, digamos ibero-americano, pela turbulência e pela agitação estéreis, como se Eusébio, Paulino ou Rodrigues Torres não fossem representantes de reivindicações tão regionais quanto às de Pernambuco, do Rio Grande do Sul ou do Pará”. Cf. MELLO, Evaldo Cabral de. Frei Caneca ou a outra Independência. In: MELLO, Evaldo Cabral de (Org.). Frei Joaquim do Amor Divino Caneca. São Paulo: Editora 34. 2001. p. 16.

${ }^{22}$ Cf. MELlO, Evaldo Cabral de (Org.). Frei Joaquim do Amor Divino Caneca, op. cit., p. 464; SILVA, Luiz Geraldo. O avesso da Independência: Pernambuco (1817-1824). In: MALERBA, Jurandir (Org.). A independência brasileira. Novas dimensões. Rio de Janeiro: Editora FGV, 2006, p. 343-384; SILVA, Luiz Geraldo. Um projeto para a nação, op. cit.; MELLO, Evaldo Cabral de. A outra independência, op. cit.; CARVALHO, Marcus J. M. de. Cavalcantis e cavalgados: a formação das alianças políticas em Pernambuco, 1817-1824. Revista Brasileira de História, v. 18, n 36, 1998.

${ }^{23}$ Cf. MONTENEGRO, Olívio. Memórias do Ginásio Pernambucano. Recife: Imprensa Oficial, 1943, p. 14.

${ }^{24}$ Embora tenha sido impresso, o Diálogo constitui panfleto apócrifo. Examinando seu conteúdo à luz de seus escritos à época e de seus textos posteriores, observamos a semelhança das ideias expostas, bem como a forma dialógica, tão recorrente nos escritos do futuro padre Carapuceiro. Talvez ainda mais decisivo seja o fato de que este, em 1825, como já vimos, controlava todo o aparato tipográfico da província. Cf. PESSOA, Reinaldo Xavier Carneiro (Org.). Diálogo entre um Corcunda, um Constitucional e um Federativo do Equador: um raro e curioso documento. São Paulo, 1975.

${ }^{25}$ Cf. Proclamação do Imperador D. Pedro I justificando a convocação de uma nova Assembleia Constituinte (13 de novembro de 1823). In: BONAVIDES, Paulo \& AMARAL, Roberto (Orgs.). Textos políticos da história do Brasil. 3.ed. Vol. I. Brasília: Senado Federal, 2002, p. 741-742; SILVA, Luiz Geraldo. Um projeto para a nação, op. cit.; MELLO, Evaldo Cabral de. A outra independência, op.cit.; BERNARDES, Denis A. de M. Pernambuco e o Império (1822-1824): sem constituição soberana não há união, op. cit., p. 219-249.

${ }^{26}$ Cf. Lei de 20 de outubro de 1823. Dá nova forma aos Governos das Províncias, criando para cada uma delas um Presidente e Conselho. Decisóes do Governo do Império do Brasil de 1823. Rio de Janeiro: Imprensa Nacional, 1887, p. 10-11.

27 Cf. SILVA, Luiz Geraldo. O avesso da Independência, op. cit.

${ }^{28}$ Cf. O Carapuceiro, no 33 (16/janeiro/1833).

${ }^{29}$ Cf. O Carapuceiro, no 40 (23/fevereiro/1833). A expressão chafana vem do espanhol, língua na qual ela é grafada como chanfaina. Em sua origem, ela tem dois sentidos: "Guisado hecho de bofes o livianos picados", ou "cargo o destino que se obtiene por influencia”. Certamente, Gama dava a expressão o segundo sentido. Cf. Diccionario de la Lengua Española. 22.ed. Madrid: Real Academia Española, 2001 (Verbete Chanfaina).

${ }^{30}$ Cf. $O$ Carapuceiro, $\mathrm{n}^{\circ} 40(23 /$ fevereiro/1833).

${ }^{31}$ Cf. O Carapuceiro, no $21(21 / 06 / 1834)$.

${ }^{32}$ Idem, ibidem.

${ }^{3}$ Idem, ibidem.

${ }^{34}$ Cf. BARATA, Cipriano. Sentinela da Liberdade e outros escritos (1821-1835), op. cit., p. 873-875.

${ }^{35}$ Idem, ibidem.

${ }^{36}$ Idem, ibidem.

${ }^{37}$ Idem, ibidem.

${ }^{38}$ Idem, ibidem.

${ }^{39}$ Idem, ibidem.

${ }^{40}$ Cf. FELDMAN, Ariel. O império das carapuças, op. cit., p. 11, 53, 60.

${ }^{41}$ Cf. CALDEIRA, Jorge (Org.). Diogo Antônio Feijó. São Paulo: Ed. 34, 1999. p. 175-177.

${ }^{42}$ Visões de conjunto sobre as revoltas regenciais foram propostas por CARVALHO, José Murilo de. Teatro de sombras, op. cit., p. 229-240, e MOREL, Marco. O tempo das regências..., p. 51-66.

${ }^{43}$ Cf. MOREL, Marco. O periodo das regências (1831-1840), op. cit., p. 30.

${ }^{44}$ Cf. Lei de 24 de outubro de 1832 - Orça a receita, e fixa a despesa para o ano financeiro de 1833-1834. Coleção das Leis do Império do Brasil de 1832. (Parte 1a). Rio de Janeiro: Typographia Nacional, 1874, p. 131-174.

${ }^{45}$ Cf. PESAVENTO, Sandra et alii. A Revolução Farroupilha. História e interpretação. Porto Alegre: Mercado Aberto, 1985; PADOIN, Maria Medianeira. A revolução farroupilha (1835-1845): fronteira e federalismo na construção do Estado nacional. Seminário Internacional Brasil: formação do Estado e da nação (1770-1850). São Paulo, USP, setembro de 2001. 
${ }^{46}$ Cf. PAOLO, Pasquale di. Cabanagem: a revolta popular na Amazônia. Belém: Cejup, 1990.

${ }^{47}$ Cf. SOUSA, Paulo Cezar. A Sabinada. Revolta separatista da Bahia (1837). São Paulo: Brasiliense, 1987.

${ }^{48}$ Cf. O Carapuceiro, no 18 (4/ abril/1838). Parece claro, ademais, que Lopes Gama estabelecia relação entre a Sabinada, de 1837/1838, e Revolta dos Malês, ocorrida em 1835, cujos líderes e revoltosos eram, principalmente, nagôs. Sobre esta revolta é absolutamente indispensável a leitura de REIS, João José. Rebeliāo escrava no Brasil. A história do levante dos malês em 1835. São Paulo: Cia. das Letras, 2003.

${ }^{49}$ A expressão latina ejusdem furfuris significa "do mesmo farelo". Atualmente, emprega-se expressão mais corriqueira, certamente uma corruptela daquela: "farinha do mesmo saco". Cf. O Carapuceiro, no 14 (14/fevereiro/1838).

${ }^{50}$ Cf. Carapuceiro, no 5 (16/janeiro/1839).

${ }^{51}$ Cf. O Carapuceiro no 66 (2/dezembro/1837), no 70 (10/dezembro/1837) e no 72 (21/dezembro/1837).

${ }^{52}$ Cf. Carapuceiro, no 5 (16/janeiro/1839).

${ }^{53}$ Cf. O Carapuceiro, no 47 (28/ julho/1838), O Carapuceiro, $\mathrm{n}^{\mathrm{o}} 14$ (3/ março/1838) e O Carapuceiro, $\mathrm{n}^{\mathrm{o}} 34$ (16/ agosto/1839).

${ }^{54}$ Cf. O Carapuceiro, no 9 (14/fevereiro/1838). Sobre as trajetórias de Saldanha e Mundurucu, ver MELO, Antônio Joaquim de. Biografia de José da Natividade Saldanha. Recife: Typographia de Manoel Figueroa Faria \& Filho, 1895; SALDANHA, José da Natividade. Da Confederação do Equador à Grã-Colômbia. Escritos políticos. Manifesto de Mundrucu. Análise e Tradução de Vamireh Chacon. Brasília: Senado Federal, 1988; SILVA, Luiz Geraldo. O avesso da Independência, $o p$. cit., p. 378-381.

${ }^{55}$ Cf. O Carapuceiro, no 70 (16/dezembro/1837).

${ }^{56}$ É possível ler os manifestos redigidos a partir de 2 de julho de 1824, por Paes de Andrade, em BONAVIDES, Paulo \& AMARAL, Roberto (Orgs.). Textos políticos da história do Brasil, op. cit., p. 786-790.

${ }^{57}$ Cf. COSTA, F. A. Pereira da. Dicionário biográfico de pernambucanos célebres, op. cit, p. 591-598 e 653-663; SILVA, Luiz Geraldo. $O$ avesso da Independência, op. cit., p. 379.

${ }^{58}$ Cf. O Carapuceiro, no 66 (2/dezembro/1837).

${ }^{59}$ Cf. QUINTAS, Amaro. O Padre Lopes Gama politico. Recife: Imprensa Universitária, 1958, p. 75-78.

${ }^{60}$ Cf: $O$ Carapuceiro, no 65 (10/agosto/1833).

${ }^{61}$ Idem, ibidem.

${ }^{62}$ Cf. BERBEL, Márcia R. A nação como artefato. Deputados do Brasil nas cortes portuguesas (1821-1822). São Paulo: Hucitec/FAPESP, 1999, p. 193; JANCSÓ, István \& PIMENTA, João Paulo G. Peças de um mosaico (ou apontamentos para o estudo de emergência da identidade nacional brasileira). In: MOTA, Carlos G. (Org.). Viagem incompleta. A experiência brasileira (1500-2000). S. Paulo: Editora SENAC, 2000.

${ }^{63}$ Cf. GUERRA, François-Xavier. A nação moderna: nova legitimidade e velhas identidades. In: JANCSÓ, István (Org.). Brasil: formação do Estado e da nação, op. cit. p. 33-60.

${ }^{64}$ Cf. O Carapuceiro, no 20 (30/maio/1839).

${ }^{65}$ Idem, ibidem.

${ }^{66}$ Data cívica unitária por excelência, o 7 de Setembro apenas foi reconhecido como data nacional em 1826. Começou, todavia, a ser comemorado apenas no ano seguinte. Até então era data menor, em comparação ao 9 de Janeiro (Dia do Fico), 25 de Março (Juramento da Constituição) e, principalmente, ao 12 de Outubro (aclamação de Dom Pedro I e fundação do Império). Cf. SOUZA, Iara Lis. Pátria coroada. O Brasil como corpo político autônomo (1780-1831). São Paulo, Editora da UNESP, 1999. p. 253.

${ }^{67}$ Cf. O Sete de Setembro, no 35, 1846. Apud: QUINTAS, Amaro. O Padre Lopes Gama político, op. cit., p. 75-78. Sobre O Sete de Setembro, ver ainda CARVALHO, Alfredo. Annaes da imprensa periódica pernambucana de 1821 a 1908, op. cit., p. 192; MELLO, Evaldo Cabral de (Org.). O Carapuceiro: crônicas de costumes, op. cit., p. 23-24.

${ }^{68}$ Cf. COSTA, F. A. Pereira da. Dicionário biográfico de pernambucanos célebres, op. cit, p. 334-352.

${ }^{69}$ Cf. TAVARES, Francisco Muniz. História da revolução de Pernambuco em 1817. 3.ed. Revista e anotada por Oliveira Lima. Recife: Imprensa Industrial, 1917 [1840], p. IV-X e LXXV-LXXVI. Embora tenha utilizado a obra de Muniz Tavares como fonte essencial de informaçôes sobre a revolução de 1817, Varnhagen critica-a ao afirmar "que está de moda adular os anais pernambucanos com a proeza dessa revolução", e que "sucessos narrados com pouco exame a vão convertendo em um mito heróico de patriotismo, não brasileiro, mas provincial, sem fundamento algum”. VARNHGEN, F. A. de. História geral do Brasil. Rio de Janeiro: Casa de E. e H. Laemmert, 1857. Tomo 2º p. 374.

${ }^{70}$ Cf. MARTINS, Joaquim Dias. Os mártires pernambucanos vítimas da liberdade nas duas revoluçôes intentadas em 1710 e 1817. Recife: Tipografia de F. C. Lemos e Silva, 1853, p. 294; MELLO, José Antonio Gonsalves de. Diário de Pernambuco, op. cit., p. 111, 167-168. 
${ }^{71}$ Cf. MELLO, Antonio Joaquim de. Obras políticas e literárias de Frei Joaquim do Amor Divino Caneca. Recife: Tipografia Mercantil, 1875. 2 tomos [3a ed., ALPE, 1979]; MELLO, Antônio Joaquim de. Biografia de José da Natividade Saldanha. Recife: Tipografia de Manoel Figueroa Faria \& Filho, 1895; MELLO, Antônio Joaquim de. Biografia de Gervásio Pires Ferreira. Recife: Editora Universitária, 1973. 2 vol.

${ }^{72}$ Cf. MELLO, Evaldo Cabral de. Rubro veio. O imaginário da restauração pernambucana. 2.ed. Rio de Janeiro: Topbooks, 1997, p. 66-69.

${ }^{73}$ Cf. Revista do Instituto Arqueológico e Geográfico Pernambucano. Ano 3, 1a tomo, 1865, p. 309-310.

${ }^{74}$ Sobre a dissimulação da política, ou o enfrentamento ideológico alheio à política, ver as análises de ELIAS, Norbert. $O$ processo civilizador. Uma história dos costumes. Trad. Ruy Jungmann. Rio de Janeiro: Jorge Zahar Editor, 1990, v. 1, p. 39; Mozart, sociologia de um gênio. Trad. Sérgio Góes de Paula. Rio de Janeiro: Jorge Zahar Editor, 1995, p. $24-25$.

${ }^{75}$ Vence o concurso em 1924 a obra de BRANDÃO, Ulysses de Carvalho Soares. A Confederação do Equador. Recife: Oficinas Gráficas da Repartição de Publicação Oficiais, 1924.

\section{Referências bibliográficas}

ANDRADE, Manuel Correia de. A Guerra dos Cabanos. Recife: Editora Conquista, s.d.

BARATA, Cipriano. Sentinela da Liberdade e outros escritos (182101835). Organização e edição de Marco Morel. São Paulo: Edusp, 2008.

BERBEL, Márcia R. A nação como artefato. Deputados do Brasil nas cortes portuguesas (1821-1822). São Paulo: Hucitec/FAPESP, 1999.

BERNARDES, Denis A. de M. Pernambuco e o Império (1822-1824): sem constituição soberana não há união. In: JANCSÓ, István (Org.). Brasil: formação do Estado e da nação. São Paulo/Injuí: Hucitec/Unijuí, 2003.

BONAVIDES, Paulo \& AMARAL, Roberto (Orgs.). Textos politicos da história do Brasil. 3.ed. Brasília: Senado Federal, 2002. vol. I.

BRANDÃO, Ulysses de Carvalho Soares. A Confederação do Equador. Recife: Oficinas Gráficas da Repartição de Publicação Oficiais, 1924.

CALDEIRA, Jorge (Org.). Diogo Antônio Feijó. São Paulo: Ed. 34, 1999 (Coleção Formadores do Brasil).

CARVALHO, Alfredo de. Annaes da imprensa periódica pernambucana de 1821 a 1908. Recife: Tipografia do Jornal do Recife, 1908.

CARVALHO, José Murilo. A construção da ordem: a elite política imperial. Teatro de sombras: a política imperial. Rio de Janeiro: Editora da UFRJ/Relume Dumará, 1996.

CARVALHO, Marcus J. M. de. Cavalcantis e cavalgados: a formação das alianças políticas em Pernambuco, 1817-1824. Revista Brasileira de História, v. 18, no 36, 1998.

CASCUDO, Luiz da Câmara. Dicionário do folclore brasileiro. São Paulo: Global, 2003.

COSTA, F. A. Pereira da. Dicionário biográfico de pernambucanos célebres. Recife: Tipografia Universal, 1882. . Vocabulário pernambucano. Recife: Editora do Brasil, 1976 [1908].

DANTAS, Leonardo. Prefácio. In: GAMA, Miguel do Sacramento Lopes. O Carapuceiro. Edição fac-similar da coleção do jornal (1832-1842). Recife: Fundação de Cultura Cidade do Recife, 1983.

DOLHNIKOFF, Miriam. Elites regionais e a construção do Estado nacional. In: JANCSÓ, István (Org.). Brasil: formação do Estado e da nação. São Paulo/Injuí: Hucitec/Unijuí, 2003.

. O pacto imperial: origens do federalismo no Brasil. São Paulo: Globo, 2005.

ELIAS, Norbert. Mozart, sociologia de um gênio. Trad. Sérgio Góes de Paula. Rio de Janeiro: Jorge Zahar Editor, 1995.

. O processo civilizador. Uma história dos costumes (vol I). Trad. Ruy Jungmann. Rio de Janeiro: Jorge Zahar Editor, 1990

FELDMAN, Ariel. Uma crítica às Instituições representativas do período das regências (1832-1840). Almanack Braziliense, no 4, nov., 2006.

FELDMAN, Ariel. Conciliar a nação: a divisão dos poderes em debate na imprensa pernambucana (18221824). Anais do XIX Encontro Regional de História da ANPUH. São Paulo: ANPUH/Seção São Paulo, 2008. 
O império das carapuças: espaço público e periodismo político no tempo das regências (1831-1842). Dissertação de Mestrado apresentada ao Programa de Pós-Graduação em História da UFPR. Curitiba, 2006.

FREYRE, Gilberto. Um ortodoxo brasileiro do século XIX. Jornal do Comércio. Recife, 17 de setembro de 1942.

Casa grande e senzala. Rio de Janeiro: José Olympio, 1951 [1933].

GUERRA, François-Xavier. A nação moderna: nova legitimidade e velhas identidades. In: JANCSÓ, István (Org.). Brasil: formação do Estado e da nação. São Paulo/Injuí: Hucitec/Unijuí, 2003.

JANCSÓ, István \& PIMENTA, João Paulo G. Peças de um mosaico (ou apontamentos para o estudo de emergência da identidade nacional brasileira). In: MOTA, Carlos G. (Org.). Viagem incompleta. A experiência brasileira (1500-2000). S. Paulo: Editora SENAC, 2000.

LEME, Mariza Saez. Dissidências regionais e articulações nacionais nos projetos de independência: o Conciliador Nacional em Pernambuco. Anais do XXIV Simpósio Nacional de História. São Leopoldo: Unisinos, 2007.

MARTINS, Joaquim Dias. Os mártires pernambucanos vítimas da liberdade nas duas revoluçôes intentadas em 1710 e 1817. Recife: Tipografia de F. C. Lemos e Silva, 1853.

MATTOS, Ilmar R. Tempo saquarema. A formação do Estado Imperial. São Paulo: Hucitec, 1990.

MELLO, Antônio Joaquim de. Biografia de Gervásio Pires Ferreira. Recife: Editora Universitária, 1973. 2 vols.

. Biografia de José da Natividade Saldanha. Recife: Tipografia de Manoel Figueroa Faria \& Filho, 1895.

. Obras políticas e literárias de Frei Joaquim do Amor Divino Caneca. Recife: Tipografia Mercantil, 1875. 2

tomos. [3a ed., ALPE, 1979].

MELLO, Evaldo Cabral de (Org.). O Carapuceiro: crônicas de costumes. São Paulo: Cia. das Letras, 1996.

. A outra independência: o federalismo pernambucano de 1817 a 1824. São Paulo: Ed. 34, 2004.

. (Org.). Frei Joaquim do Amor Divino Caneca. São Paulo: Editora 34, 2001 (Coleção Formadores do Brasil).

. Rubro veio. O imaginário da restauração pernambucana. 2.ed. Rio de Janeiro: Topbooks, 1997.

MELLO, José Antonio Gonsalves de. Diário de Pernambuco. Economia e Sociedade no 2º. Reinado. Recife: Editora Universitária da UFPE, 1996.

MONTENEGRO, Olívio. Memórias do Ginásio Pernambucano. Recife: Imprensa Oficial, 1943.

MOREL, Marco. As transformaçôes dos espaços públicos. Imprensa, atores políticos e sociabilidades na cidade imperial (1820-1840). São Paulo: Hucitec, 2005.

NASCIMENTO, Luis do. História da imprensa de Pernambuco (1821-1954). Recife: Editora Universitária, 1969. vol. IV.

PADOIN, Maria Medianeira. A revolução farroupilha (1835-1845): fronteira e federalismo na construção do Estado nacional. Seminário Internacional Brasil: formação do Estado e da nação (1770-1850). São Paulo, USP, setembro de 2001.

PALLARES-BURKE, Maria Lúcia Garcia. Nisia Floresta, O Carapuceiro e outros ensaios de tradução cultural. São Paulo: Hucitec, 1996.

PAOLO, Pasquale di. Cabanagem: a revolta popular na Amazônia. Belém: Cejup, 1990.

PESAVENTO, Sandra et alii. A Revolução Farroupilha. História e interpretação. Porto Alegre: Mercado Aberto, 1985.

PESSOA, Reinaldo Xavier Carneiro (Org.). Diálogo entre um Corcunda, um Constitucional e um Federativo do Equador: um raro e curioso documento. São Paulo, 1975.

QUINTAS, Amaro. O Padre Lopes Gama político. Recife: Imprensa Universitária, 1958.

REIS, João José. Rebelião escrava no Brasil. A história do levante dos malês em 1835. São Paulo: Cia. das Letras, 2003.

SALDANHA, José da Natividade. Da Confederação do Equador à Grã-Colômbia. Escritos políticos. Manifesto de Mundrucu. Análise e Tradução de Vamireh Chacon. Brasília: Senado Federal, 1988.

SILVA, Luiz Geraldo. O avesso da Independência: Pernambuco (1817-1824). In: MALERBA, Jurandir (Org.). A independência brasileira. Novas dimensōes. Rio de Janeiro: Editora FGV, 2006.

. Um projeto para a nação. Tensões e intenções políticas nas "Províncias do Norte". Revista de His-

tória (USP). Vol. 158, $1^{\circ}$ sem. de 2008. 
SOUSA, Paulo Cezar. A Sabinada. Revolta separatista da Bahia (1837). São Paulo: Brasiliense, 1987.

SOUZA, Iara Lis. Pátria coroada. O Brasil como corpo político autônomo (1780-1831). São Paulo, Editora da UNESP, 1999.

TAVARES, Francisco Muniz. História da revolução de Pernambuco em 1817. 3. ed. Revista e anotada por Oliveira Lima. Recife: Imprensa Industrial, 1917 [1840].

VALENTE, Waldemar. O Padre Carapuceiro: crítica de costumes na primeira metade do século XIX. Recife: Departamento de Cultura da Secretaria de Educação e Cultura, 1969.

VARNHAGEN, F. A. de. História geral do Brasil. Rio de Janeiro: Casa de E. e H. Laemmert, 1857.

\section{RESUMO}

Este artigo analisa a contra-memória criada no período regencial em torno dos movimentos políticos pernambucanos de 1817 e 1824, propagada principalmente através do jornal O Carapuceiro (1832-1842), publicado por Miguel do Sacramento Lopes Gama. Procuramos demonstrar que esse periódico foi, sobretudo, político e não, meramente de costumes, e que teve grande influência no processo de retorno dos conservadores ao poder, em 1837. Examinamos, também, como a memória sobre aqueles eventos foi redefinida, entre as décadas de 1840 e 1860, como resultado da publicação de obras, como a de Muniz Tavares (História da Revolução de Pernambuco em 1817), e da fundação do Instituto Arqueológico e Geográfico Pernambucano (1862) que procuraram instituir outra contra-memória daqueles movimentos, articuladamente à construção de uma identidade provincial e contraposta à identidade imperial, forjada no âmbito do $I H G B$ e da historiografia produzida em seu interior.

Palavras-chave: memória; espaço público; Pernambuco; revolução; federalismo.

\section{ABSTRACT}

This article analyzes the counter-memory elaborated during the regency period over Pernambuco's political movements of 1817 and 1824, disseminated mainly through O Carapuceiro (1832-1842), newspaper edited by Miguel do Sacramento Lopes Gama. We try to demonstrate that this newspaper was mainly political, and not merely cultural, and that it had great influence in the process of the return of conservatives to power in 1837. We also examine how the memory of those events has been redefined between the decades of 1840 and 1860 as a result of the publication of works such as the History of the Pernambuco Revolution in 1817, written by Muniz Tavares, and of the foundation of the Pernambuco Archeological and Geographic Institute, in 1862, which have aimed to create another counter-memory of those movements, articulating that with the construction of a provincial identity opposed to the imperial identity forged within the IHGB and of the historiography produced there.

Keywords: memory; public sphere; Pernambuco; revolution; federalism. 